\title{
Evaluation of circulating endothelial cells in the rat after acute and fractionated whole-body gamma irradiation
}

Ghassan Al-Massarani, Khaled Almohamad

\begin{abstract}
Purpose: Damage to vascular endothelial cells is a well recognised complication of the irradiation. Our objective was to determine the gamma-irradiation effect on the rat circulating endothelial cells (CEC). Material and methods: Eight-week old rats were divided into four groups: group 1 - rats were exposed to acute whole-body gamma irradiation with a wide range of single doses $(0.5,1,2,4$ and $8 \mathrm{~Gy})$, group 2 - rats were exposed to fractionated low doses of irradiation $(0.1,0.5$ and $1 \mathrm{~Gy})$ every three days for two months, group 3 as group 2 , but followed by two months of rest, group 4 were control animals. CEC (CD146 positive cells) in group 1 were counted following CD146-based immuno-magnetic separation after one day and one week, as well as at the end of experiment in the other groups. Results: Quantified CEC showed that there was a dose-dependent reduction in CEC count in group 1 (one week after irradiation) and group 2. A partial re-population of CEC was observed at the end of experiment in both group 1 and group 2 compared to control group. Group 3 showed a significant increase in CEC levels as compared with group 2 without reaching the control level. Conclusion: The number of CEC (CD146 positive cells) in rats exposed to whole-body gamma irradiation was reduced in a dose-dependent manner and it partly recovered during the two-month interval after irradiation. We suggest that CEC count may be an indicator of the radiation-induced vascular damage.
\end{abstract}

Key words: whole-body gamma irradiation • acute irradiation $\bullet$ fractionated irradiation $\bullet$ biomarkers $\bullet$ circulating endothelial cells • endothelial damage

\section{G. Al-Massarani ${ }^{\bowtie}$}

Biomarkers Laboratory,

Department of Radiation Medicine,

Atomic Energy Commission of Syria (AECS),

Tel.: +963 213 2580, Fax: +963116112289,

E-mail: ascientific@aec.org.sy

\section{K. Almohamad}

Hematological Diseases Laboratory,

Department of Radiation Medicine,

Atomic Energy Commission of Syria (AECS)

Received: 3 June 2014

Accepted: 25 September 2014

\section{Introduction}

Recently, acute or chronic radiation exposure, such as that of A-bomb survivors or nuclear industry workers, has been revealed to be strongly associated with circulatory diseases $[1,2]$. However, with few exceptions, little is known about how ionizing radiation exposure induces cardiac or circulatory diseases [3, 4]. Vascular endothelium is implicated as one of radiation targets, leading to the development of cardiovascular diseases.

In this context, the endothelial dysfunction plays an important role in promoting fibrotic and inflammatory processes after irradiation [5]. Radiation-induced endothelial injury has been described as a crucial event in initiation of normal tissue damage [6]. Endothelial dysfunction is mainly characterised by the loss of thrombo resistance, which is accompanied by a decreased expression of the adhesion molecules and of the Von-Willebrand factor. Previous studies have reported endothelial dysfunction in both human [7] and animal subjects [8-10] exposed to ionizing radiation.

Endothelial cell dysfunction after irradiation can be recognised by morphological changes, such as cell swelling [11], increased leukocyte-endothelial 
cell adherence and infiltration of leukocytes into tissues [12-15]. Also, it can be recognised by the adhesion of platelets to the vascular wall [16], the loss in vascular wall integrity resulting from reduced endothelial cell numbers and the formation of tortuous vessels [17].

During the last years, it has been evidenced that endothelium is a highly dynamic tissue in equilibrium with a circulating compartment composed of various sub-populations offering important opportunities for a noninvasive exploration. Among these, the circulating endothelial cells (CECs) are noninvasive markers of vascular damage and dysfunction [18]. CECs are mature cells shed from blood vessel walls during the natural process of endothelial cell turnover and renewal. These cells are heterogeneous in size $(15-50 \mu \mathrm{m})$, carry the markers of endothelial cells (e.g.: Von Willebrand factor, CD144, and CD146), and do not have leukocyte markers (CD45) [19]. Changes in CEC levels in peripheral blood possibly reflect endothelial cell dysfunction, which may have occurred due to some environmental conditions such as altitude [20]. So, CEC evaluation in peripheral blood may be used as research tool to determine the effect of exposure to various external factors, including ionizing radiation.

Recent studies have reported that total body irradiation initiates rapid endothelial injury and that CEC in venous blood are a marker of endothelial damage [21, 22]. Moreover, in our recent study, we have demonstrated that chronic exposure to low dose of ionizing radiation leads to significant changes in CEC level [23].

The aim of the present study was to investigate whether whole-body irradiation with a wide range of single doses $(0.5-8 \mathrm{~Gy})$ or fractionated radiation schedule (0.1-1 Gy, every three days for two months) could affect the CEC level in the blood of rats.

\section{Materials and methods}

\section{Animals}

Eight weeks of age Wistar rats were used. This strain was initially obtained from Charles Rivers Laboratories (France) and then it was raised in our animal facility. The animals were handled according to the recommendations of the Declaration of Helsinki and the internationally accepted principles for the care and use of experimental animals. Both control $(N=8)$ and experimental animals $(N=64)$ were kept under stable microenvironment conditions $\left(22 \pm 1^{\circ} \mathrm{C}\right)$, with alternating $12 \mathrm{~h}$ light and dark cycles and received standard laboratory food and water.

\section{Irradiation}

Acute and fractionated whole-body gamma irradiation $(116 \mathrm{mGy} / \mathrm{m})$ was administered to rats using gamma ray apparatus (Theratron 80 Canadian design machine, Co-60, focal distance of $100 \mathrm{~cm}$ ) located in our laboratories. During irradiation, rats were restrained in special irradiation-cages containing from 5 up to 10 rats at the same time. There was no change in housing, standard food or drinking water following irradiation. The animals were closely observed for unwanted effects and there was no visible sign of discomfort or illness. Age-matched, non-irradiated rats served as controls.

\section{Experimental design}

Rats were randomly divided into four groups; one group served as control and the other three groups served as experimental groups. The first group of rats was exposed to acute whole-body gamma irradiation with $0.5,1,2,4$ and $8 \mathrm{~Gy}$, respectively, (dose rate $116 \mathrm{mGy} / \mathrm{min}$ ). Animals in the second group were exposed to fractionated whole-body gamma irradiation of $0.1,0.5 \mathrm{~Gy}$ and $1 \mathrm{~Gy}$, respectively, every three days for two months. The third group was fractionally exposed to low dose of $0.1,0.5$ and 1 Gy every three days for two months, followed by two months without any irradiation for observation of late repair of the vascular endothelium in the irradiated rodents.

\section{Blood collection}

Under general anesthesia, the abdomen was opened up through a midline incision; a $25 \mathrm{G}$ needle was inserted in the inferior vena cava and blood was drawn into a citrate containing tube for the immuno-magnetic separation (IMS) analysis of CEC; then, the animal was killed via cervical dislocation.

\section{Detection and quantification of circulating endothelial cells}

For immuno-magnetic isolation and quantification of endothelial cells, we used monodispersed magnetisable particles (Dynal M450 IgG1, Dynal AS, Oslo, Norway). The $4.5 \mu \mathrm{m}$ diameter polystyrene beads were coated with affinity-purified Pan-anti-mouse immunoglobulin G1 covalently bound to the surface. The beads were washed according to the manufacturer's protocol, with a strong magnet (MPC6, Invitrogen, CA, USA) used to remove sodium azide. Typically, $100 \mu \mathrm{L}$ of microbead suspension was coated non-covalently with $10 \mu \mathrm{g} / \mathrm{mL}$ EPR3208, a rabbit monoclonal antibody against CD146 (Abcam, Cambridge, UK), a pan-rat endothelial cell-specific monoclonal antibody diluted 1:10 in phosphate buffered saline (PBS) with $0.1 \%$ bovine serum albumin (BSA) and $0.1 \%$ sodium azide, by overnight incubation at $4^{\circ} \mathrm{C}$ with head-over-head agitation. After three washes with PBS-BSA-NaN3 to remove excess antibody, the beads were resuspended in buffer until use. One millilitre $(\mathrm{ml})$ of the blood was diluted $1: 3$ with the isolation buffer and incubated for 1.5 hours at $4^{\circ} \mathrm{C}$ on a rotator with $15 \mu \mathrm{l}\left(7 \times 10^{7}\right.$ microbeads $)$ 


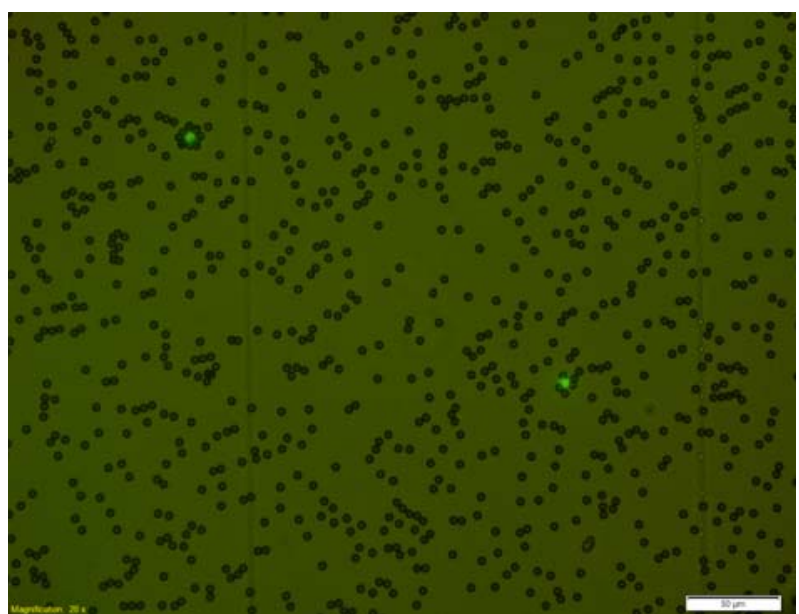

Fig. 1. Quantification of circulating endothelial cells in blood; typical aspect of fluorescent bead-rosetted endothelial cells. CEC stained with acridine orange, photographed under fluoresent microscope, magnification $\times 20$.

of a preparation of anti-CD146-coupled magnetic beads. Separation of beads and rosetted cells from the blood samples required a minimum of 2 minutes exposure to the magnet.

Three washes were performed to completely remove non-rosetted cells. After the third wash, the rosetted cells were recovered in a $100 \mu \mathrm{L}$ solution of acridine orange (at a final concentration of $5 \mu \mathrm{g} / \mathrm{mL}$ in PBS), and observations were made in a $0.5 \mathrm{~mm}$. Nageotte chamber cytometer (Hecht-Assistent, Sondheim, Germany) under fluorescent microscope (BX51, Olympus, Japan) equipped with a $500 / 20 \mathrm{~nm}$ excitation filter. The quality of images was improved by software Deltapix version 1.6 (Deltapix, Måløv, Denmark).

CEC seen under ultraviolet light after staining with acridine orange were identified as $15-50 \mu \mathrm{m}$ diameter cells bearing five beads, or as cells with five beads and with a well-preserved and recognisable morphology (clear nucleus in a well-defined cytoplasm, and a size compatible with that of endothelial cells) [24]. Representative photographs of CEC are shown in Fig. 1.

\section{Results}

\section{Survival}

All animals in the control and irradiated groups survived the whole experimental period. Body weight gain and food intake in the irradiated rats were not significantly different from those in the control group.

\section{CEC in normal rats}

The median number of circulating endothelial cells in normal rats was 161 cells/mL (range 102-218 cells $/ \mathrm{mL}$ ). There were no differences in CEC count between the male and female normal rats (mean \pm SEM: $175 \pm 39$ cells $/ \mathrm{ml}$ vs. $154 \pm 17$ cells $/ \mathrm{ml}, p=0.9$ )

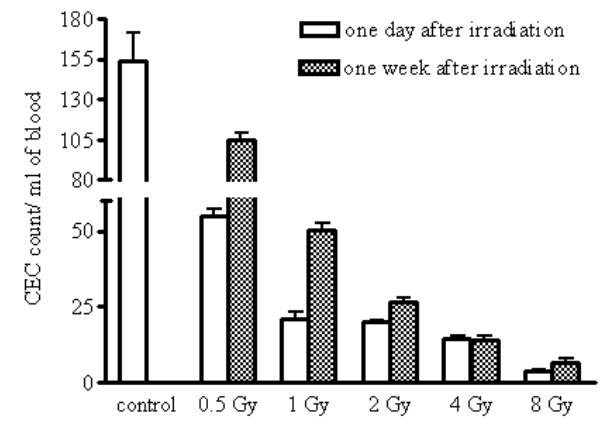

Fig. 2. Dose-response for early radiation-induced reduction of the CEC count and a partial re-population of CEC one week after acute irradiation. CEC numbers were scored one day (open) and one week (dashed) after acute irradiation. Compared to control group, rats irradiated with $0.5,1,2,4$ and 8 Gy radiation had significantly lower CEC number. Each data column represents the mean CEC count in four rats, except for control group which contains eight rats. Error bars are standard error of the mean (SEM).

\section{Radiation dose-dependent changes in CEC number following single acute dose}

Rats were irradiated with a single gamma ray dose of 2,4 and $8 \mathrm{~Gy}$, operated at a dose-rate of $116 \mathrm{mGy} / \mathrm{min}$. The acute whole-body gamma irradiation of rats resulting in significant reduction in CEC number at all three doses studied compared with those in the control group (Fig. 2). The CEC count was significantly decreased in a dose-dependent manner one day and one week after single dose of 2 , 4 , and $8 \mathrm{~Gy}$. Also, single doses of irradiation less than 2 Gy (0.5 and $1 \mathrm{~Gy})$ were applied to rats. A single dose of 0.5 and 1 Gy caused a significantly lower CEC count compared to control (Fig. 2). Results of the present investigation show that low and moderate single doses applied for whole-body irradiation affect the endothelial detachment balance.

Radiation dose-dependent changes in CEC number following repeated fractionated dose

All irradiated rats had significantly lower number of CEC compared to control group (Fig. 3). A dose-dependent decrease in CEC count was observed in the rats following two months fractionated low dose whole-body irradiation.

\section{Partial re-population of CEC count in rats after discontinuation of irradiation}

One week after single dose of irradiation, we observed a significant increase in the number of CEC at doses less than $2 \mathrm{~Gy}$ compared to the results found one day after irradiation (at $0.5 \mathrm{~Gy} p=0.0017$, at 1 Gy $p=0.002$, at $2 \mathrm{~Gy} p=0.04$ ). This increase, one week after irradiation, does not reach normal levels of CEC in non-irradiated rats. However, no significant difference was found in CEC count one 


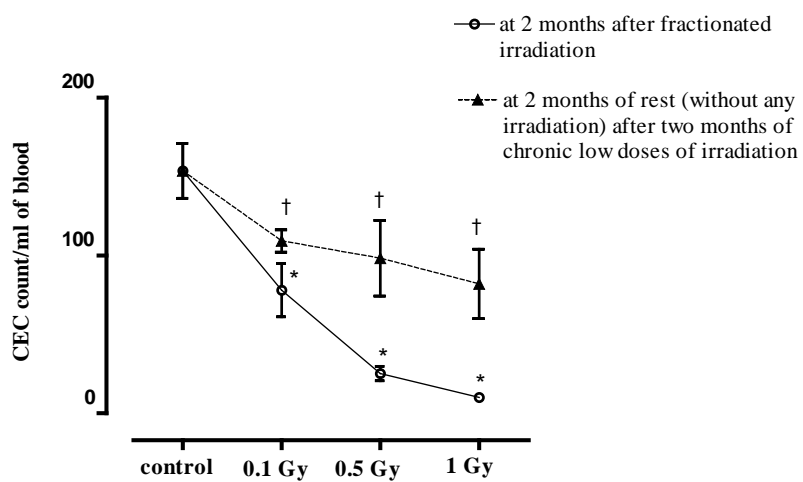

Fig. 3. Dose-response for early radiation-induced reduction of CEC count and partial re-population of CEC after two months of stopping of fractionated irradiation. CEC numbers were scored immediately (solid line) after completing the 2 months fractionated irradiation and after 2 months fractionated irradiation, followed by 2 months of rest (without any irradiation) (dashed line). Compared to control group, rats irradiated with $0.1,0.5$ and $1 \mathrm{~Gy}$ radiation had significantly lower CEC number. Each data point represents the mean CEC count in four rats, except for control group which contains eight rats. Error bars are standard error of the mean (SEM). $\left({ }^{*} p<0.05\right.$ with respect to the control, $+p<0.05$ with respect to the rats irradiated every 3 days for 2 months).

week after irradiation compared to those found one day after irradiation in rats irradiated acutely with 4 Gy and 8 Gy (see Fig. 2).

In the group of rats exposed to low gamma ray doses every three days for two months followed by two months of rest, a significant increase in the number of CEC took place at each radiation dose after two months of irradiation, followed by two months of rest, as compared with that found immediately after two months of fractionated irradiation (see Fig. 3).

\section{Discussion}

To the best of our knowledge, this is the first experimental study, which investigates the early effect of acute irradiation with moderate and high dose of radiation and the late effect of fractionated irradiation with low and moderate dose of radiation on the circulating endothelial cells (CD146 positive) in blood of rats. The vascular endothelium is a strong target candidate for radiation-induced damage due to its high radio-sensitivity [25].

Endothelial cells are recognised as target of the early radiation-induced apoptosis and are likely involved in delayed vascular necrosis. Accumulating evidences indicate that CEC in venous blood serve as a biomarker of endothelial damage [26, 27]. Vascular injury is associated with increase or decrease of CECs [20, 24, 28]. So, we assessed the endothelium damage inflicted by gamma radiation by measuring CEC levels. We chose in vivo model in order to study a complete system, where all cell types and physiological responses are included.

Originally, we found a dose-dependent marked reduction in CEC numbers one day after acute single dose of irradiation with $0.5,1,2,4$ and 8 Gy compared to those in controls. This is consistent with the notion of the very short duration of the apoptotic process in vivo [29]. This early loss in CECs number was maintained for up to seven days after irradiation. The alterations observed in cell numbers were expected as irradiation diminishes the clonogenic capacity of endothelial cells in vitro and causes their depletion in vivo from the vasculature $[30,31]$. These results conflict with the hypothesis of dysfunctional endothelial cells being detached. Possibly, the reduced CEC numbers in irradiated rats may point to different mechanisms of endothelial damage and repair, rather than to detachment of dysfunctional endothelial cells. It has been showed that CD146+ circulating cells, beside CECs, contain a subpopulation of progenitor endothelial cells (EPC) [32]. Hence, the decreased CEC in blood of irradiated rats might indicate inadequate EPC numbers, which impair endothelial cell replacement and thereby compromise integrity of endothelium in irradiated rats.

The early decrease in the number of endothelial cells after irradiation has been postulated to be due partly to apoptosis of the endothelial cell population $[33,34]$. Our results demonstrate a gradual decline in CEC count after irradiation and are consistent with this notion.

Radiation doses ranging from $2 \mathrm{~Gy}$ to $50 \mathrm{~Gy}$ have been shown to induce endothelial cell apoptosis in vitro [35-37] or in vivo [33]. Accordingly, ionizing radiation was shown to induce ceramide-mediated endothelial cell apoptosis in vivo [33, 38, 39]. The vulnerability of the endothelium to radiation-induced apoptosis appears to be related to the high level of acid sphingomyelinase expression in endothelial cells (approximately 20 -fold higher than in macrophages [40]), and to its preferential trafficking to the plasma membrane.

Also, several previous studies have demonstrated that the early vascular changes following irradiation within $24 \mathrm{~h}$ include increased vascular permeability, endothelial cell swelling, neutrophil adhesion to the endothelium [41] and apoptosis [33, 35, 36, 42, 43]. Langley and coworkers [44] has been found that apoptotic microvascular endothelial cells in suspension were particularly fragile after irradiation with 2-10 Gy. We assume that CEC count decrease after whole-body irradiation of rats is due to early damage of the cytoplasmic membranes of endothelial cells. It is caused by irradiation, as proposed by Salovsky [45] presumably by disruption of the cytoskeleton [46] or by CD146 loss after irradiation. We have yet to confirm this directly. It should be noted that Klein-Soyer and coworkers observed that the endothelial cell layer after irradiation was always continuous in their experimental system, without signs of desquamation [47]. Zhou and coworkers [48] noted that cell detachment $24 \mathrm{~h}$ after irradiation of the bovine aortic endothelial cells (BAEC) with high doses of radiation (5 Gy or $10 \mathrm{~Gy}$ ) was significantly lower than that in the unirradiated cells [48]. Therefore, further studies are needed to verify the hypothesis of the increased adhesion of endothelial cells after irradiation. 
Whereas the present study provided evidence for the radiation-induced CECs loss, prior investigation by Zeng et al. [22] showed an increase in CECs $\left(\mathrm{CD} 31^{+}, \mathrm{CD} 133^{-}\right.$, and CD45 $\left.{ }^{\text {low }}\right)$ count at five and seven days after irradiation in mice exposed to lethal-intensity $(8.5 \mathrm{~Gy})$ and reduced-intensity (5 Gy) irradiation. Differences in the CEC count assay may have accounted for this apparent discrepancy. We explain this difference by the use of CD31 as an endothelial marker by Zeng et al. [22]. CD31 is not specific for the endothelium and can be detected on leukocyte subsets or platelet/leukocytes aggregates. Indeed, on the basis of CD31-bright/ CD45-negative labeling as a combination to identify CEC, the amount of cells recorded per milliliter of blood is about 1000 - to 100000 -fold higher than the level of CEC consensually reported in normal and pathological settings using CD146 based immuno-magnetic separation that was used in our study. This huge discrepancy raises the question of the nature of CD31-bright/CD45-negative population in the study of Zeng et al. [22].

Recently, the biological effect of low dose radiation on cellular response has received attention, because low radiation doses also could induce serious health effects $[49,50]$. Here, we used lower radiation doses in order to more closely mimic the clinical setting. However, no studies have been reported on the effects of doses lower than 1 Gy on CEC in vivo. Interestingly, our study shows the influence of fractionated low and moderate doses of irradiation on CEC levels in rats irradiated every three days for two months. We found a dose-dependent significant reduction in CEC numbers at two months after fractionated irradiation with $0.1,0.5$ and $1 \mathrm{~Gy}$ compared to those in controls.

This finding demonstrates the importance of CEC enumeration in the evaluation of vascular damage caused by irradiation even with doses less than $2 \mathrm{~Gy}$, that have a minimal lethal effect in endothelial cells in vitro, as reported in previous studies $[51,52]$.

We further examined the recovery from endothelial damage. To investigate this issue, rats were exposed to fractionated low doses of radiation every three days for two months followed by two months recovery period. It is truly amazing that we found a significant increase in the CEC count two months after the end of fractionated irradiation, although it did not reach the control level (i.e. in the unirradiated rats).

Vascular endothelial cells have a slow turnover in vivo. It has been reported that ionizing radiation also may have dual roles with respect to endothelial cells, angiogenesis and the microenvironment: whereas radiation has a dominant direct anti-endothelial effect, it may also convey an indirect pro-angiogenic effect to endothelium [53]. Re-population of CEC that occurs after two months of rest of the following fractionated irradiation with low doses $(<2 \mathrm{~Gy})$ may be due to endothelial cell proliferation after irradiation. Newly generated endothelial cells have been shown to migrate within capillaries to replace the damaged endothelial cells [54]. This result suggests that the damage caused by fractionated low doses of gamma rays can be repaired and that the endothelial cell injury possibly plays a role in early, but not late, vascular injury. More detailed studies are required for elucidation of the radiation injury at the cellular level and of the re-population process.

In summary, we provide an evidence of the important role for the circulating (CD146 positive) endothelial cell enumeration in monitoring the endothelial damage in rats after acute and fractionated gamma irradiation.

Acknowledgment. We are indebted to Mrs. Esra `a Banat, Mrs. Nisreen Al-Mala and Mrs. Fatima Al-Sheikh for their technical assistance.

\section{References}

1. Adams, M. J., Hardenbergh, P. H., Constine, L. S., \& Lipshultz, S. E. (2003). Radiation-associated cardiovascular disease. Crit. Rev. Oncol. Hematol., 45(1), 55-75. DOI: http://dx.doi.org/10.1016/S10408428(01)00227-X.

2. Shimizu, Y., Kodama, K., Nishi, N., Kasagi, F., Suyama, A., Soda, M., Grant, E. J., Sugiyama, H., Sakata, R., Moriwaki, H., Hayashi, M., Konda, M., \& Shore, R. E. (2010). Radiation exposure and circulatory disease risk: Hiroshima and Nagasaki atomic bomb survivor data, 1950-2003. BMJ, 340, b5349. Retrieved January 14, 2010, from PubMed database on the World Wide Web: http://www.pubmed.gov. DOI: $10.1136 / \mathrm{bmj} . \mathrm{b} 5349$.

3. Little, M. P., Gola, A., \& Tzoulaki, I. (2009). A model of cardiovascular disease giving a plausible mechanism for the effect of fractionated low-dose ionizing radiation exposure. PLoS Comput. Biol., 5(10), e1000539. Retrieved October 23, 2009, from PubMed database on the World Wide Web: http://www. pubmed.gov. DOI: 10.1371/journal.pcbi.1000539.

4. Halle, M., Gabrielsen, A., Paulsson-Berne, G., Gahm, C., Agardh, H. E., Farnebo, F., \& Tornvall, P. (2010). Sustained inflammation due to nuclear factor-kappa $\mathrm{b}$ activation in irradiated human arteries. J. Am. Coll. Cardiol., 55(12), 1227-1236. DOI: 10.1016/j. jacc.2009.10.047.

5. Boerma, M., \& Hauer-Jensen, M. (2011). Preclinical research into basic mechanisms of radiation-induced heart disease. Cardiol. Res. Pract. Retrieved October 4, 2010, from PubMed database on the World Wide Web: http://www.pubmed.gov. DOI: $10.4061 / 2011 / 858262$.

6. Bentzen, S. M. (2006). Preventing or reducing late side effects of radiation therapy: radiobiology meets molecular pathology. Nat. Rev. Cancer, 6(9), 702-713. DOI: 10.1038/nrc1950.

7. Sugihara, T., Hattori, Y., Yamamoto, Y., Qi, F. Ichikawa, R., Sato, A., Liu, M. Y., Abe, K., \& Kanno, M. (1999). Preferential impairment of nitric oxide-mediated endothelium-dependent relaxation in human cervical arteries after irradiation. Circulation, 100(6), 635-641. DOI: 10.1161/01.CIR.100.6.635.

8. On, Y. K., Kim, H. S., Kim, S. Y., Chae, I. H., Oh, B. H., Lee, M. M., Park, Y. B., Choi, Y. S., \& Chung, M. H. (2001). Vitamin C prevents radiation-induced endothelium-dependent vasomotor dysfunction and de-endothelialization by inhibiting oxidative damage in the rat. Clin. Exp. Pharmacol. Physiol., 28(10), 816-821. DOI: 10.1046/j.1440-1681.2001.03528.x. 
9. Qi, F., Sugihara, T., Hattori, Y., Yamamoto, Y., Kanno, M., \& Abe, K. (1998). Functional and morphological damage of endothelium in rabbit ear artery following irradiation with cobalt60. Br. J. Pharmacol., 123(4), 653-660. DOI: 10.1038/sj.bjp.0701654.

10. Soloviev, A. I., Tishkin, S. M., Parshikov, A. V., Ivanova, I. V., Goncharov, E. V., \& Gurney, A. M. (2003). Mechanisms of endothelial dysfunction after ionized radiation: selective impairment of the nitric oxide component of endothelium-dependent vasodilation. Br. J. Pharmacol., 138(5), 837-844. DOI: 10.1038/ sj.bjp.0705079.

11. Robbins, M. E., Jaenke, R. S., Bywaters, T., Golding, S. J., Rezvani, M., Whitehouse, E., \& Hopewell, J. W. (1993). Sequential evaluation of radiation-induced glomerular ultrastructural changes in the pig kidney. Radiat. Res., 135(3), 351-364.

12. Narayan, K., Withers, R., Garcia, C., Masoh, K., \& Kumar, S. (1994). Guinea pig spinal cord as a model for the study of late radiation injury and repair. Int. J. Oncol., 4(4), 809-814. DOI: 10.3892/ijo.4.4.809.

13. Ward, H. E., Kemsley, L., Davies, L., Holecek, M., \& Berend, N. (1993). The pulmonary response to sublethal thoracic irradiation in the rat. Radiat. Res., 136(1), 15-21.

14. Panes, J., Anderson, D. C., Miyasaka, M., \& Granger, D. N. (1995). Role of leukocyte-endothelial cell adhesion in radiation induced microvascular dysfunction in rats. Gastroenterology, 108(6), 1761-1769.

15. Kimura, H., Wu, N. Z., Dodge, R., Spencer, D. P., Klitzman, B. M., McIntyre, T. M., \& Dewhirst, M. W. (1995). Inhibition of radiation-induced upregulation of leukocyte adhesion to endothelial cells with the platelet-activating factor inhibitor, BN52021. Int. J. Radiat. Oncol. Biol. Phys., 33(3), 627-633. DOI: http://dx.doi.org/10.1016/03603016(95)00205-D.

16. Verheji, M., Dewit, L. G., Boomgaard, M. N., Brinkman, H. J., \& Mourik, J. A. (1994). Ionizing radiation enhances platelet adhesion to the extracellular matrix of human endothelial cells by an increase in the release of von Willebrand factor. Radiat. Res., 137(2), 202-207.

17. Law, M. P. (1981). Radiation induced vascular injury and its relation to late effects in normal tissues. Adv. Radiat. Biol., 9, 37-73.

18. Woywodt, A., Blann, A. D., Kirsch, T., Erdbruegger, U., Banzet, N., Haubitz, M., \& Dignat-George, F. (2006). Isolation and enumeration of circulating endothelial cells by immunomagnetic isolation: proposal of a definition and a consensus protocol. J. Thromb. Haemost., 4(3), 671-677. DOI: 10.1111/j.15387836.2006.01794.X.

19. Goon, P. K., Lip, G. Y., Boos, C. J., Stonelake, P. S., \& Blann, A. D. (2006). Circulating endothelial cells, endothelial progenitor cells, and endothelial microparticles in cancer. Neoplasia, 8(2), 79-88. DOI: 10.1593/neo.05592.

20. Mancuso, P., Peccatori, F., Rocca, A., Calleri, A., Antoniotti, P., Rabascio, C., Saronni, L., Zorzino, L., Sandri, M. T., Zubani, A., \& Bertolini, F. (2008). Circulating endothelial cell number and viability are reduced by exposure to high altitude. Endothelium, 15(1), 53-58. DOI: 10.1080/10623320802092344.

21. Woywodt, A., Scheer, J., Hambach, L., Buchholz, S., Ganser, A., Haller, H., Hertenstein, B., \& Haubitz, M. (2004). Circulating endothelial cells as a marker of endothelial damage in allogenic hematopoietic stem cell transplantation. Blood, 103(9), 3603-3605. DOI: 10.1182/blood-2003-10-3479.
22. Zeng, L., Yan, Z., Wang, L., Du, B., Pan, X., \& Xu, K. (2008). Irradiation is an early determinant of endothelial injury during hematopoietic stem cell transplantation. Transplant. Proc., 40 (8), 2661-2664. DOI: $10.1016 / \mathrm{j}$.transproceed.2008.08.062.

23. Al-Massarani, G., \& Najjar, F. (2013). Does occupational exposure to low ionizing radiation affect endothelium health? Nukleonika, 58(4), 527-531.

24. Blann, A. D., Woywodt, A., Bertolini, F., Bull, T. M., Buyon, J. P., Clancy, R. M., Haubitz, M., Hebbel, R. P., Lip, G. Y., Mancuso, P., Sampol, J., Solovey, A., \& Dignat-George, F. (2005). Circulating endothelial cells. Biomarker of vascular disease. Thromb. Haemost., 93(2), 228-235. DOI: http:/dx.doi. org/10.1160/TH04-09-0578.

25. Menendez, J. C., Casanova, D., Amado, J. A., Salas, E., García-Unzueta, M. T., Fernandez, F., de la Lastra, L. P., \& Berrazueta, J. R. (1998). Effects of radiation on endothelial function. Int. J. Radiat. Oncol. Biol. Phys., 41(4), 905-913. DOI: http://dx.doi.10.1016/ S0360-3016(98)00112-6.

26. Burger, D., \& Touyz, R. M. (2012). Cellular biomarkers of endothelial health: microparticles, endothelial progenitor cells, and circulating endothelial cells. $J$. Am. Soc. Hypertens., 6(2), 85-99. DOI: 10.1016/j. jash.2011.11.003.

27. Erdbruegger, U., Haubitz, M., \& Woywodt, A. (2006). Circulating endothelial cells: A novel marker of endothelial damage. Clin. Chim. Acta, 373(1/2), 17-26.

28. Garbuzova-Davis, S., Woods III, R. L., Louis, M. K., Zesiewicz, T. A., Kuzmin-Nichols, N., Sullivan, K. L., Miller, A. M., Hernandez-Ontiveros, D. G., \& Sanberg, P. R. (2010). Reduction of circulating endothelial cells in peripheral blood of ALS patients. Plos ONE 5(5), e10614. Retrieved May 12, 2010, from PubMed database on the World Wide Web: http://www. pubmed.gov. DOI: 10.1371/journal.pone.0010614.

29. Barres, B. A., Hart, I. K., Coles, H. S., Burne, J. F., Voyvodic, J. T., Richardson, W. D., \& Raff, M. C. (1992). Cell death and the control of survival in the oligodendrocyte lineage. Cell, 70(1), 31-46.

30. Wang, J., Kumar, S., van Agthoven, A., Kumar, P., Pye, D., \& Hunter, R. D. (1995). Irradiation induces upregulation of E9 protein (CD105) in human vascular endothelial cells. Int. J. Cancer, 62 (6), 791-796. DOI: 10.1002/ijc.2910620624.

31. Hirst, D. G., Denekamp, J., \& Hobson, B. (1980). Proliferation studies of the endothelial and smooth muscle cells of the mouse mesentery after irradiation. Cell Tissue Kinet., 13(1), 91-104.

32. Delorme, B., Basire, A., Gentile, C., Sabatier, F., Monsonies, F., Desouches, C., Blot-Chabaud, M., Uzan, G., Sampol, J., \& Dignat-George, F. (2005). Presence of endothelial progenitor cells, distinct from mature endothelial cells, within human CD146+ blood cells. Thromb. Haemost., 94(6), 1270-1279. DOI: http:// dx.doi.org/10.1160/TH05-07-0499.

33. Pena, L. A., Fuks, Z., \& Kolesnick, R. N. (2000). Radiation-induced apoptosis of endothelial cells in the murine central nervous system: protection by fibroblast growth factor and sphingomyelinase deficiency. Cancer Res., 60(2), 321-327.

34. Li, Y., Chen, P., Haimovitz-Friedman, A., Reilly, R. M., \& Wong, C. S. (2003). Endothelial apoptosis initiates acute blood-brain barrier disruption after ionizing radiation. Cancer Res., 63(18), 5950-5956.

35. Bonnaud, S., Niaudet, C., Pottier, G., Gaugler, M. H., Millour, J., Barbet, J., Sabatier, L., \& Paris, F. (2007). Sphingosine-1-phosphate protects proliferating endothelial cells from ceramide-induced apoptosis but not 
from DNA damage-induced mitotic death. Cancer Res., 67(4), 1803-1811. DOI: 10.1158/0008-5472. CAN-06-2802.

36. Khodarev, N. N., Kataoka, Y., Murley, J. S., Weichselbaum, R. R., \& Grdina, D. J. (2004). Interaction of amifostine and ionizing radiation on transcriptional patterns of apoptotic genes expressed in human microvascular endothelial cells (HMEC). Int. J. Radiat. Oncol. Biol. Phys., 60(2), 553-563. DOI: http:// dx.doi.org/10.1016/j.ijrobp.2004.04.060.

37. Nübel, T., Damrot, J., Roos, W. P., Kaina, B., \& Fritz, G. (2006). Lovastatin protects human endothelial cells from killing by ionizing radiation without impairing induction and repair of DNA double-strand breaks. Clin. Cancer Res., 1(12), 933-939. DOI: 10.1158/1078-0432.CCR-05-1903.

38. Santana, P., Pena, L. A., Haimovitz-Friedman, A., Martin, S., Green, D., McLoughlin, M., Cordon-Cardo, C., Schuchman, E. H., Fuks, Z., \& Kolesnick, R. (1996). Acid sphingomyelinase-deficient human lymphoblasts and mice are defective in radiation-induced apoptosis. Cell, 86(2), 189-199. DOI: http:// dx.doi.org/10.1016/S0092-8674(00)80091-4.

39. Paris, F., Fuks, Z., Kang, A., Capodieci, P., Juan, G., Ehleiter, D., Haimovitz-Friedman, A., Cordon-Cardo, C., \& Kolesnick, R. (2001). Endothelial apoptosis as the primary lesion initiating intestinal radiation damage in mice. Science, 293(5528), 293-297. DOI:10.1126/science.1060191.

40. Marathe, S., Schissel, S. L., Yellin, M. J., Beatini, N., Mintzer, R., Williams, K. J., \& Tabas, I. (1998). Human vascular endothelial cells are a rich and regulatable source of secretory sphingomyelinase. Implications for early atherogenesis and ceramide mediated cell signaling. J. Biol. Chem., 273(7), 4081-4088. DOI: 10.1074/jbc.273.7.4081.

41. Farjado, L. F., Brown, J. M., \& Glastein, E. (1976). Glomerular and juxtaglomerular lesions in radiation nephropathy. Radiat. Res., 68(1), 177-183. DOI: $10.2307 / 3574547$

42. Baker, D. G., \& Krochak, R. J. (1989). The response of the microvascular system to radiation: a review. Cancer Invest., 7(3), 287-294.

43. Eissner, G., Kohlhuber, F., Grell, M., Ueffing, M., Scheurich, P., Hieke, A., Multhoff, G., Bornkamm, G. W., \& Holler, E. (1995). Critical involvement of transmembrane tumor necrosis factor-alpha in endothelial programmed cell death mediated by ionizing radiation and bacterial endotoxin. Blood, 86(11), 4184-4193.
44. Langley, R. E., Bump, E. A., Quartuccio, S. G., Medeiros, D., \& Braunhut S. J. (1997). Radiation-induced apoptosis in microvascular endothelial cells. Br. J. Cancer, 75(5), 666-672. DOI:10.1038/ bjc.1997.119.

45. Salovsky, P. T., \& Shopova, V. L. (1992). Early biological effects of whole body irradiation on rat lungs. Radiat. Environ. Biophys., 31(4), 333-341. DOI: 10.1007/BF01210213.

46. Savla, U., \& Waters, C. M. (1998). Barrier function of airway epithelium: effects of radiation and protection by keratinocyte growth factor. Radiat. Res., 150(2), 195-203.

47. Klein-Soyer, C., Beretz, A., Cazenave, J. P., Driot, F., \& Maffrand, J. P. (1990). Behavior of confluent endothelial cells after irradiation. Modulation of wound repair by heparin and acidic fibroblast growth factor. Biol. Cell., 68(1/3), 231-238. DOI: 10.1016/02484900(90)90313-R.

48. Zhou, M., Dong, Q., \& Ts'ao, C. (1988). Susceptibility of irradiated bovine aortic endothelial cells to injury. Am. J. Pathol., 133(2), 277-284.

49. Luckey, T. D. (2008). The health effects of low-dose ionizing radiation. J. Am. Phys. Surg., 13(2), 39-42.

50. Suzuki, K., \& Yamashita, S. (2012). Low-dose radiation exposure and carcinogenesis. Jpn. J. Clin. Oncol., 42(7), 563-568. DOI: 10.1093/jjco/hys078.

51. Ahmad, M., Khurana, N. R., \& Jaberi, J. E. (2007). Ionizing radiation decreases capillary-like structure formation by endothelial cells in vitro. Microvasc Res., 73(1), 14-19. DOI: 10.1016/j.mvr.2006.08.005.

52. Salloum, R. M., Jaskowiak, N. T., Mauceri, H. J. Seetharam, S., Beckett, M. A., Koons, A. M., Hari, D. M., Gupta, V. K., Reimer, C., Kalluri, R., Posner, M. C., Hellman, S., Kufe, D. W., \& Weichselbaum, R. R. (2000). NM-3, an isocoumarin, increases the antitumor effects of radiotherapy without toxicity. Cancer Res., 60(24), 6958-6963.

53. Abdollahi, A., Lipson, K. E., Weber, K. J., Hahnfeldt, P., Hlatky, L., Debus, J., Howlett, A. R., \& Huber, P. (2003). SU5416 and SU6668 decrease angiogenic effects of radiation-induced factor productions by tumour cells and amplify the direct anti-endothelial action of radiation in vitro. Cancer Res., 63(13), 3755-3763.

54. Krum, J. M., Kenyon, K. L., \& Rosenstein, J. M. (1997). Expression of blood-brain barrier characteristics following neuronal loss and astroglial damage after administration of anti-Thy-1 immunotoxin. Exp. Neurol., 146(1), 33-45. 